Warszawa

\title{
Grupa Agora - poszukiwanie drogi rozwoju
}

$\mathrm{M}^{\mathrm{s}}$ edia mają do wypełnienia określoną misję. Ale żeby mogły tego dokonać, muszą w miarę sprawnie funkcjonować w otoczeniu gospodarczym. W tym sensie każde wydawnictwo, stacja radiowa lub telewizyjna jest przedsiębiorstwem, realizuje wytyczoną przez siebie strategię, której celem jest zapewnienie mu rozwoju lub chociażby przetrwania.

Spróbujmy spojrzeć na firmę medialną jak na organizm gospodarczy. Ponieważ najlepiej operować przykładem, posłużmy się casusem Grupy Agora, wydawcy „Gazety Wyborczej”. Owa spółka o ambicjach koncernu multimedialnego, z uporem realizowanych, stanowi fenomen polskiego rynku prasowego, podręcznikowy wręcz przykład, ,wstrzelenia się” w zachodzące przemiany gospodarcze.

Od dłuższego czasu Agorę oglądamy wyłącznie przez pryzmat nowelizacji ustawy medialnej i związanych z tym perturbacji. Spójrzmy na nią jak na przedsiębiorstwo, które 22 października ubiegłego roku - w dniu, w którym koncern Axel Springer Verlag wprowadził na rynek dziennik „Fakt” - stanęło przed nowym wyzwaniem ekonomicznym. Zastanówmy się, jak było do tego przygotowane.

Cofnijmy się na chwilę o kilkanaście lat.

Współczesne dojrzewanie polskiego rynku prasowego rozpoczyna się na początku lat 90-tych i trwa całą dekadę. Ma dość spokojny, ewolucyjny charakter. Sprzyjają temu szybko rosnące wpływy z reklamy - w latach 1996-1999 przychody mediów pochodzące z tego źródła rosną niemal 3-krotnie, znacznie wyprzedzając wzrost PKB ${ }^{1}$. Głównym beneficjentem jest telewizja (w 2000 roku trafia do niej 48\% wydatków reklamowych), kolejne miejsce zajmuje właśnie prasa $(38 \%)^{2}$.

Wyraźnie nabierają kształtu poszczególne segmenty rynku prasowego, główni gracze stopniowo wzmacniają swoje pozycje - w pierwszym rzęPKB.

${ }^{1}$ W 1999 roku stanowią one blisko 1,4\% PKB, gdy w 1996 roku - około 0,6\%

2 Dane, odpowiednio, AGB-Polska i Agora Monitoring. 
dzie metodą przejęć. Następuje klasyczny „rozbiór” rynku: niemiecki holding Verlagsgruppe Passau (reprezentowany przez Grupę Wydawniczą Polskapresse) i norweska Orkla Press przejmują i dzielą między siebie segment prasy regionalnej. Grupa Bauer dystansuje innych wydawców czasopism. Nie zagrożonymi liderami na rynku dzienników ogólnopolskich są trzy gazety („Gazeta Wyborcza”, „Super Express”, „Rzeczpospolita”) - inaczej pozycjonowane, co zapewnia im dość spokojną koegzystencję.

Spośród wymienionej trójki największe ,pretensje” rynkowe zgłasza, bez wattpienia, "Gazeta Wyborcza” i wydająca ją Grupa Agora. Owa spółka o ambicjach koncernu multimedialnego, z uporem realizowanych, stanowi fenomen polskiego rynku prasowego, podręcznikowy wprost przykład „wstrzelenia się” w zachodzące przemiany gospodarcze.

Wydawca, rozpoczynający w 1989 roku od 8-stronicowej broszury wyborczej o nakładzie 80 tysięcy egzemplarzy (popularyzującej kandydatów „Solidarności” w wyborach do Sejmu), po dziesięciu latach żywiołowego rozwoju jest spółką akcyjną notowaną (od 20 kwietnia 1999 roku) na warszawskiej giełdzie. Zaczynając od zera, ma w 1999 roku w ujęciu skonsolidowanym odnoszącym się do stworzonej w 1998 roku Grupy Agora - majątek trwały o wartości blisko $509 \mathrm{mln}$ zł, przychody netto $\mathrm{W}$ wysokości $690 \mathrm{mln}$ zł i zysk netto ponad $132 \mathrm{mln}$ zł. Jest pracodawcą przeszło 2500 ludzi. Na fali koniunktury zaczyna agresywnie inwestować - w rozgłośnie radiowe (od 1996 roku), płatną telewizję (od 1997 roku jest udziałowcem TKP S.A., właściciela płatnego kanału telewizyjnego Canal+ Polska ${ }^{3}$ ) i Internet (od 1999 roku). Pragnąc zmniejszyć zależność od usług zewnętrznych buduje od podstaw (1998 rok) nowoczesną drukarnię offsetową w Tychach i planuje dalsze inwestycje w bazę poligraficzna, których przewidywana wartość w latach 1999-2001 ma się zamknąć kwotą $400 \mathrm{mln}$ zł.

Co zadecydowało, że w ciągu dekady spółka rozpoczynająca od autentycznego zera osiagnnęła sukces na miarę największego w Polsce i szóstego w Europie (pod względem nakładu) dziennika opiniotwórczego? Z pewnością nie byłby on możliwy bez przemian gospodarczych i politycznych, które stworzyły lukę podażową na krajowym rynku prasowym. Szeregowi członkowie 10-milionowego związku zawodowego „Solidar-

3 Ale już rok później rozwodnia swoje udziały (zmniejszenie zaangażowania z $22,5 \%$ do, kolejno, $17,9 \%$ i 12,12\%), nie partycypując w kolejnych podniesieniach kapitału. 
ność" poszukiwali własnego, bliskiego im ideowo źródła informacji o kraju i świecie. Nim ten pierwotny „elektorat” „Gazety Wyborczej” uległ z czasem stopniowej atomizacji - zaś sam dziennik utracił oficjalny ,protektorat" związku - tytuł zdążył wrosnąc w krajobraz polskich mediów, zyskując charakter uniwersalny.

Kapitalną rolę odegrał również rynek reklamy, rosnący w tych latach w tempie powyżej $20 \%$ rocznie. W początkowej fazie rozwoju spółka cierpiała na permanentny brak wolnych środków niezbędnych do finansowania szybko zwiększanego nakładu dziennika ${ }^{4}$. Ich stałe, dominujące źródło znalazła w rynku ogłoszeń - rosnąca dosłownie w oczach sieć biur ogłoszeń zapewniła jej wkrótce pozycję największego ogłoszeniobiorcy na rynku prasowym ${ }^{5}$. Ugruntowane z czasem przekonanie o wyjątkowej skuteczności lokowania reklam właśnie w „Gazecie Wyborczej” pozwala jej zarazem na prowadzenie nader ,,aroganckiej” polityki cenowej w tym zakresie. Nie znaczy to jednak, że ceny reklam podnoszone są „w ciemno". Zorganizowany przez spółkę system analizy rynku ukierunkowany zostaje na codzienne monitorowanie pozycji i cenników konkurentów, ich bieżącego i przewidywanego udziału w rynku. Od pewnego momentu Agora Monitoring staje się nie tylko narzędziem realizującym wewnętrzne zadania nałożone przez Grupę, ale także jednym z istotnych źródeł informacji dla całego rynku medialnego.

Podobnie nowatorski charakter miał stworzony przez Agorę system kontroli dystrybucji. W przeciwieństwie do innych wydawców pasywnie „akceptujących” kompletny bezwład organizacyjny i monopolistyczne nawyki krajowego dystrybutora prasy (RUCH-u), spółka wprowadziła do jego sieci grupę własnych kontrolerów, dostarczających firmie niezależnych danych na temat rzeczywistego popytu na dziennik w poszczególnych rejonach kraju. Stają się one podstawowym materiałem analitycznym niezbędnym do kolejnego eksperymentu - stworzenia dualnej struktury „Gazety”, w której obok części krajowej pojawia się dodatek regionalny. W 1998 roku tytuł jest zarazem dziennikiem ogólnopolskim jak i konglomeratem 20 dzienników lokalnych pokrywających zasięgiem cały kraj,

4 Jedyny zagraniczny inwestor bezpośredni, Cox Poland Investment, Inc. (własność amerykańskiego koncernu Cox Enterprises, Inc.) został udziałowcem Agory w 1993 roku.

5 Według własnych szacunków Agory w 1998 roku „Gazeta Wyborcza” miała około 9-procentowy udział w łącznych wydatkach na reklamę w Polsce we wszystkich mediach i około 45-procentowy udział w wydatkach na reklamę w dziennikach. 
redagowanych w Warszawie (strony ogólnopolskie i edycja stołeczna) i 17 redakcjach regionalnych. Jak należy przypuszczać, nie budzi to zachwytu Polskapresse i Orkli, będąc dla nich właściwie jedynym realnym zagrożeniem zewnętrznym przy pozyskiwaniu reklam prasowych. Dla Agory ten model organizacyjno-wydawniczy, zapewniając szereg korzyści, stanowi zarazem duże obciążenie finansowe - jak się z czasem okaże, do zaakceptowania jedynie w okresie rynkowej prosperity.

Fakt stopniowego obudowywania „Gazety” przez dodatki tematyczne i weekendowe oraz charakter zmian w jej układzie graficznym (z wykorzystaniem koloru i fotografii, na co pozwala coraz nowocześniejsza baza poligraficzna) zdaje się wskazywać na rosnące ambicje jej zespołu redakcyjnego, czerpiącego szereg wzorów z prasy zachodnioeuropejskiej. Podsyca je kierownictwo Agory, w 1998 roku inicjując program uczestnictwa pracowników we własności firmy. Grono współudziałowców zostaje poszerzone do 96 osób z kadry kierowniczej. Rok później, w ramach oferty publicznej, akcjonariuszami staje się 1530 pracowników spółki.

List do akcjonariuszy, którym zarząd Grupy Agora podsumowuje zarówno 1999 rok, jak i całe dziesięciolecie istnienia firmy, jest - co naturalne przy dobrej kondycji spółki oraz całego rynku medialnego - pełen obietnic przyszłego dynamicznego rozwoju. Stanowi wizję koncernu multimedialnego zdolnego „...zmierzyć się z wyzwaniami globalizacji [...]”. Celem jest ,...ekspansja na rynku polskim, a z czasem - europejskim [...]”. Kluczowy ma być moment wstapienia do Unii. ,...Zadaniem kierownictwa firmy jest zapewnienie, aby do tego czasu Agora stała się silnym i aktywnym graczem w europejskiej konsolidacji mediów [...]”.

Zdarza się, że zarządy koncernów zaślepione wdrażaniem własnej ambitnej strategii nie są zdolne, a czasami wręcz bronią się przed dostrzeżeniem i przyjęciem do wiadomości coraz bardziej wyraźnych oznak sygnalizujących zmiany w otoczeniu gospodarczym. Długi okres stabilnego wzrostu wyrabia w nich przekonanie, że pojawiający się regres będzie krótkotrwały i płytki. Paradoksalnie, sprawnie kierując firmą w czasach prosperity, zatracają zdolność szybkiej, wyprzedzającej reakcji na kryzys i skutecznego przeciwstawiania się jego skutkom.

Pierwsze lata istnienia Agory stanowią okres jej żywiołowego rozwoju w sprzyjającym otoczeniu. Wejście w proces upubliczniania spółki, zakończony w 1999 roku debiutem na giełdzie, wymusza na niej szereg działań porządkujących ten ,żywioł”. Ciagle jednak strategia Grupy realizowana jest w warunkach pro-rozwojowych, ukrywających przy tym jej rzeczywistą odporność na zmiany czynników zewnętrznych. Surowym, obiektyw- 
nym recenzentem staną się dopiero nadchodzące lata kryzysu gospodarczego i załamanie rynku mediów i reklamy.

\section{Trzy lata z życia Agory}

\section{Agora 2000 - przed zakrętem}

Rok 2000 jest, jak się później okaże, ostatnim rokiem solidnych, dwucyfrowych przyrostów odnotowywanych w rachunku wyników Agory. Skonsolidowane przychody netto Grupy wzrosną o 17,5\%, marża EBITDA o $33,8 \%$, zaś wynik netto o $31,2 \%$.

Za najważniejszy cel zarząd firmy uznaje budowanie długoterminowej wartości dla akcjonariuszy. W praktyce oznacza to kilka kierunków działań o znaczeniu fundamentalnym dla całej spółki, w tym w pierwszym rzędzie:

- aktywne uczestnictwo w poziomej konsolidacji polskiego rynku medialnego;

- maksymalne uniezależnienie się od czynników zewnętrznych, powiązane z racjonalizacją kosztów.

Grupa kontynuuje inwestycje w segmencie radiowym. Rozszerza posiadany portfel o kolejne 4 stacje, osiaggając liczbę 14 rozgłośni lokalnych, co zapewnia jej łączny udział w silnie konsolidującym się ogólnopolskim rynku reklamy radiowej na poziomie 10,5\% (i zarazem trzecie miejsce na rynku, za potentatami - RMF FM i Radiem ZET).

Te liczby robią wrażenie, ale jedynie w niewielkim stopniu przybliżają cel Grupy: dywersyfikację źródeł przychodów. Chociaż w 2000 roku skonsolidowane łączne przychody grupy radiostacji rosną aż o 38\% (brzmi dobrze), wynoszą w sumie zaledwie $38,1 \mathrm{mln}$ zł - przy $615,3 \mathrm{mln}$ zł wpływów ze sprzedaży ogłoszeń w „Gazecie Wyborczej” i dalszych 153,7 mln zł ze sprzedaży nakładu tejże „Gazety”. Mimo podejmowanych wysiłków jeden dziennik dostarcza blisko 95\% skonsolidowanych przychodów całej Grupy, zaś przychody grupy radiostacji mają nadal na tyle marginalny charakter, że nawet w sensie księgowym przedsięwzięcie nie podlega konsolidacji jako niespełniające warunku istotności według polskich zasad księgowości ${ }^{6}$.

6 Do skonsolidowanych wyników finansowych Grupy zaliczone zostały w Raporcie Rocznym za 2001 rok jedynie operacje Agory S.A. i Agory Poligrafia Sp. z o.o. 
Kolejnej swojej szansy Agora szuka w Internecie. Następuje szybki wzrost przychodów ze sprzedaży reklam. Rozpoczęte zostają prace nad budową portalu. Równocześnie kontynuowany jest rozwój elektronicznej wersji „Gazety Wyborczej” i internetyzacja Agory w ramach projektu Internet (nowy system gromadzenia i zarządzania materiałem redakcyjnym, skoordynowany ze stronami internetowymi i portalem). Grupa zawiązuje z ComputerLand S.A. spółkę Centrum Handlu Internetowego Sp. z o.o. do prowadzenia internetowego pasażu handlowego. Z perspektywy budowania długoterminowej wartości Grupy te przedsięwzięcia są w pełni racjonalne, będą jednak wymagać jeszcze wiele czasu i inwestycji, aby mogły zrealizować swój potencjał rozwojowy.

Zdecydowanie szybsze efekty przynoszą działania podjęte w kierunku uniezależniania się od czynników zewnętrznych. Zakończona zostaje rozbudowa bazy poligraficznej - dysponując 3 własnymi nowoczesnymi drukarniami w Tychach, Pile i warszawskiej Białołęce Agora stopniowo lokuje całość produkcji i druku offsetowego we własnych zakładach (nadwyżka ich mocy produkcyjnych pozwala też na świadczenie usług poligraficznych). Wolumen produkcji powierzony drukarniom zewnętrznym spada w 2000 roku do 19,2\% (druk w technikach nieoffsetowych). Wdrażana jest strategia oddziałowa poprzez rozdzielenie dystrybucji na trzy oddziały strategiczne - „Gazeta Wyborcza” pozostaje jedynym dziennikiem w Polsce, któremu udaje się odnotować wzrost nakładu sprzedanego.

Warto zatrzymać się na moment przy motywacji, jaka kierowała realizowaniem przez Grupę inwestycji w baze poligraficzną. Oczywistym zamiarem jest kwestia zmniejszenia uzależnienia od dostawców zewnętrznych (także w celu ograniczenia kosztów operacyjnych). Celem jest jednak również poprawienie względnej sytuacji firmy poprzez wpływanie działaniami strategicznymi na równowagę sił w sektorze. Kierownictwo Agory wyraźnie dostrzega aspekt barier wejścia w podejmowanej przez nią integracji wstecz. Nie tając tego w swoich wypowiedziach oświadcza, że ,...zabezpieczenie dostatecznych mocy produkcyjnych jest również istotnym narzędziem konkurencyjnym, stwarza bowiem bariery wejścia na rynek $[\ldots]^{\prime \prime 7}$.

W warunkach szybkiego rozwoju w 2000 roku kwestia racjonalizacji kosztów nie spędza jeszcze snu z oczu zarządowi Grupy. Nowe przedsię-

7 Komentarz zarządu do Raportu Rocznego za 2000 rok. 
wzięcia i rozwój dotychczasowych powodują, że na koniec grudnia zatrudnienie osiąga poziom 3400 pracowników (o 20,8\% więcej niż w analogicznym okresie roku ubiegłego). Wydaje się, że daleko większe znaczenie przykładane jest do kosztowych czynników zewnętrznych, chociażby do zaopatrzenia w surowce i materiały ${ }^{8}-\mathrm{w}$ pierwszym rzędzie w papier do druku „Gazety Wyborczej”, kupowany na bazie kontraktów terminowych na stałą cenę w markach niemieckich. Wydatki na papier są niebagatelne, stanowią niemal 1/3 kosztów operacyjnych (liczonych bez amortyzacji). Problem poziomu zatrudnienia i związanych z tym kosztów pojawi się dopiero w warunkach narastającej recesji na rynku mediów w roku następnym. Nie znaczy to oczywiście, że od pracowników nie oczekuje się odpowiedniego zaangażowania. Działa pion HR kierowany przez pracownika w randze dyrektora, tworzone są plany motywacyjne dla kadry kierowniczej i dziennikarzy oraz system nagród przyznawanych w drodze konkursu. Strategia firmy przekładana jest na cele indywidualne dla poszczególnych kierowników, te zaś są bazą rocznych planów motywacyjnych.

W połowie 2000 roku Agora staje przed problemem zupełnie nowej natury. 1 lipca ustają ograniczenia zbywalności akcji pracowniczych. Ich nagłe, nieskoordynowane pojawienie się na rynku może poważnie zachwiać kursem walorów spółki. Aby temu przeciwdziałać - w interesie zarówno Grupy jak i sprzedających - zorganizowano wspólną sprzedaż za pośrednictwem jednego z czołowych banków inwestycyjnych. Problem rozwiązano poprzez transakcje pakietowe o niebagatelnej wartości $181,5 \mathrm{mln}$ zł. Dodatkowo przedmiotem obrotu staje się ponad 704 tysiące akcji posiadanych przez pracowników szczebla kierowniczego. W swoim ówczesnym komentarzu prezes zarządu Agory stwierdziła, że ,...wspólna sprzedaż dowiodła, że pracownicy wierzą w długoterminowy sukces Agory i zachowali znaczną część akcji jako inwestycję na przyszłość [...]”. Czy istniały podstawy do takiej oceny? Chyba jednak był to optymizm na pokaz. Decyzję o sprzedaży posiadanych akcji zbywalnych podjęło 1148 z 1530 pracowników będących akcjonariuszami spółki. Co więcej, na ten sposób szybkiego zrealizowania zysków zdecydowało się aż 57 spośród

8 Podczas, gdy w 1999 roku koszt zakupionych surowców i materiałów stanowił $35,2 \%$ całości ponoszonych kosztów, w 2000 roku obniża się do 32,9\% (przy stabilnych cenach zakupów). Tymczasem udział kosztów wynagrodzeń i świadczeń dla pracowników rośnie w tym okresie z $29,1 \%$ do $31,4 \%$. 
96 osób z kadry kierowniczej objętej zainicjowanym zaledwie dwa lata wcześniej programem uczestnictwa we własności firmy.

Grupa zamyka 2000 rok zyskiem netto w wysokości 174,1 mln zł. Dysponuje wolnymi środkami w wysokości $38 \mathrm{mln}$ zł w gotówce i 151,5 mln zł w krótkoterminowych papierach wartościowych. Przychody netto rosną do poziomu $810,7 \mathrm{mln}$ zł. I jest tylko jeden problem, wspomniany już na wstępie. Grupa żyje z „Gazety Wyborczej” - a to oznacza, że wystarczy podważenie przez konkurencję pozycji tego jednego tytułu, aby zachwiać całym koncernem. Z Komentarza zarządu do Raportu Rocznego za 2000 rok wyraźnie widać determinację w kierunku strukturalnego zrównoważenia Agory.

Przedstawiając akcjonariuszom strategię na 2001 rok zarząd Grupy zwraca ich uwagę w pierwszym rzędzie na swój zamiar:

- umacniania pozycji Agory na rynku medialnym poprzez kontynuację rozwoju organicznego istniejących przedsięwzięć (w tym przekształcenie projektów internetowych w przedsięwzięcia biznesowe);

- wykorzystania posiadanej płynności finansowej do poszerzenia skali operacyjnej poprzez dalsze fuzje i przejęcia obejmujące nowe gałęzie działalności medialnej (przedsięwzięcia wydawnicze, radiowo-telewizyjne, internetowe i reklamowe);

- wejścia w inwestycje strategiczne, alianse i wspólne przedsięwzięcia (skierowane wyłącznie w stronę sektora medialnego);

- prognozowania kosztów i aktywnego zarządzania zapasami (dotyczy to w pierwszym rzędzie papieru).

Powyższe hasłowo zarysowane przez zarząd założenia wskazują na plany dalszej agresywnej strategii inwestycyjnej. Agora nieustannie liczy czas pozostający do momentu wstąpienia Polski do Unii Europejskiej i pełnego otwarcia polskiego rynku medialnego. Rozwija się niezwykle dynamicznie, ale w ciągłym poczuciu, że może jej zabraknąć kilku lat do odpowiedniego usytuowania firmy na rynku i stworzenia wystarczających barier wejścia dla potencjalnych nowych konkurentów.

Przyjęta strategia oparta zostaje na prognozie ekonomicznej, jak się z czasem okaże, zbyt optymistycznej. Analizując ogólną sytuację gospodarczą i rynek medialny założono:

- wzrost PKB w 2001 roku w granicach 4\%;

- wzrost rynku prasowego o $14 \%$;

- wzrost sumarycznych wydatków na reklamę o $12,5 \%{ }^{9}$.

9 Prognoza Zenith Media wyniosła zaledwie 8\%. 
Uznano tym samym, że stabilizujący się rynek reklamy będzie działał w warunkach słabszego wzrostu gospodarczego. Nastapi wzmożona konkurencja w sferze spółek medialnych. Mimo to, dzięki silnej pozycji rynkowej „Gazety Wyborczej”, Grupa ma uzyskać wzrost przychodów z reklamy, choć skromniejszy niż w latach poprzednich.

Te założenia boleśnie zweryfikuje nadchodzący rok. W swojej prognozie Agora wyraźnie nie doszacowała skalę i głębokość nadciągającego kryzysu gospodarki polskiej i rynku mediów.

\section{Agora 2001 - koniec hossy}

Począwszy od 2000 roku Agora z coraz większą uwagą śledzi zmiany w relacjach między wydatkami na reklamę na rynku krajowym, a wzrostem lub spadkiem PKB. Do 2000 roku wzrost rynku reklamy wyprzedzał wzrost PKB. Od tego momentu tendencja zaczyna ulegać odwróceniu. Tę nową sytuację kierownictwo Grupy interpretuje jako dojrzewanie rynku reklamy, w którym coraz większą rolę odgrywają czynniki makroekonomiczne. Oceniono, że rynek reklamy przestał nadrabiać „stare zaległości” z minionych dziesięcioleci, zaś najważniejszą siłą napędową jego wzrostu staje się rosnący PKB. W rok później - gdy wydatki na reklamę zaczynają gwałtownie maleć i, co gorsza, ich spadek od pewnego momentu staje się znacznie głębszy niż realny spadek PKB - zmieniono akcenty w ocenie, skupiając uwagę również na mikroekonomicznych przyczynach tej zupełnie nowej sytuacji na rynku mediów. Za pierwszorzędne uznano pogarszająca się płynność finansową reklamodawców, gwałtowny spadek ich rentowności i narastające wątpliwości ich kierownictw co do zdolności gospodarki do szybkiego przełamania kryzysu. To oznaczało, że szykuje się długa, wyczerpująca walka rynkowa o malejące budżety reklamowe, cięte często na oślep przez przedsiębiorstwa przerażone spadającymi dochodami.

W przeciwieństwie do ogólnej tendencji na rynku reklamy (spirala redukcji stawek w odpowiedzi na malejące wydatki reklamowe) Agora wierząc w swoją pozycję rynkową - traktuje nadal ogłoszenia prasowe jako dobro rzadkie i utrzymuje ich wysoki poziom cenowy (godząc się ze spadkiem liczby reklamodawców i, w efekcie, powierzchni ogłoszeniowej). Ocenione to zostanie jako opłacalna strategia. Nie uda się co prawda obronić wolumenu przychodów (wartość sprzedaży ogłoszeń na łamach „Gazety Wyborczej” w 2001 r. spada o 9,3\%), ale też w tym samym czasie rynek reklam płatnych gazet codziennych w Polsce kurczy się wartościowo 
o 10,9\%. Niemal połowa jego obrotów (ponad 47\%) pozostaje w rękach „Gazety”. Taktyce twardej polityki cenowej Agory towarzyszą zarazem odczuwalne oszczędności na kosztach papieru gazetowego, szczególnie istotne przy jego wzrastających cenach.

W 2001 roku „Gazeta Wyborcza” jako jedyny dziennik ogólnopolski zwiększa swój średni nakład sprzedany (o symboliczne 0,3\%). Ma też najlepszy współczynnik udziału nakładu sprzedanego w całości wydania (78,8\% - przy 75,7\% w przypadku „Rzeczpospolitej” i 76,3\% - „Super Expressu”). Należy przypuszczać, że wpływ na to mają podjęte działania (niektóre kosztowne), służące uatrakcyjnieniu „Gazety”. Zaraz po rozpoczęciu roku szkolnego dziennik zostaje obudowany nowym dodatkiem dla uczniów („Kujon Polski”), rozbudowie - przy zmodyfikowanej infografice - ulegają kolumny gospodarcze, dotąd nie należące do najsilniejszych stron tytułu. „Podpompowaniu” nakładu służąjednorazowe dodatki („Ustawa uwłaszczeniowa”, „Wykup swoje mieszkanie”), konkurs „Dukaty" i dołączone 6 płyt CD (wigilijna płyta z pastorałkami pomaga w ustanowieniu rekordu nakładu wydania - 1380 tys. egzemplarzy). W listopadzie następuje włączenie dotychczasowych dodatków lokalnych do głównego wydania „Gazety Wyborczej” - pod hasłem nadania im takiej samej rangi, jak innym działom (starannie przemilczany jest oszczędnościowy aspekt tego przedsięwzięcia).

Agora jest wyraźnie dumna z wyników osiagniętych przez „Gazetę” w 2001 roku. Niewątpliwie ma się z czego cieszyć, ale ten medal ma drugą stronę. Jeden dziennik dostarcza około 94\% skonsolidowanych przychodów całej Grupy, praktycznie tyle samo, co rok wcześniej. Co gorsza, kontynuowana strategia dywersyfikacji jest kosztowna i napotyka na wiele przeszkód, a niektóre nowe przedsięwzięcia potrzebować będąjeszcze lat, by zrealizować swój potencjał rozwojowy. W pierwszym rzędzie dotyczy to Internetu.

Gazeta.pl - portal internetowy z 21 serwisami lokalnymi obejmującymi wszystkie regiony i miasta wojewódzkie Polski - ma osiagnąć równowagę finansową dopiero w 2003 roku. Póki co, roczna wartość usług internetowych wynosi skromne $3,8 \mathrm{mln}$ zł (tylko o 200 tysięcy złotych więcej, niż rok wcześniej), zaś inwestycje w projekt Internet zamykają się w kwocie blisko 18 mln zł. Tym samym, wbrew wcześniejszym założeniom, segment internetowy nie staje się w 2001 roku przedsięwzięciem biznesowym. Kierownictwo Grupy ocenia go jednak jako ważny dla długofalowego wzrostu wartości firmy i nie podejmuje nerwowych kroków w celu wyjścia z tej inwestycji. 
Rozrastająca się szybko grupa posiadanych radiostacji lokalnych zwiększa w sumie swój udział w rynku, ale ich łączne przychody spadają (o 0,8\%, do 37,8 mln zł). Również TOK FM (41,6\% udziałów Agory) generuje straty. W celu poprawy efektywności finansowej wdrażana jest strategia precyzyjnego formatowania stacji radiowych na podstawie badań marketingowych.

Całkowicie nowym przedsięwzięciem dywersyfikującym działalność Grupy jest wejście w segment prasy bezpłatnej. Stanowi to ratowanie udziału w rynku reklamy dynamicznie pozyskiwanym przez bezpłatne gazety i magazyny zainicjowane przez innych wydawców. Nie zabierają one zbyt wielu czytelników ,poważnej” prasie opiniotwórczej, ale ich rosnące nakłady przyciagają reklamodawców. Kiedy w 2000 roku ukazał się nowy stołeczny tygodnik bezpłatny „Dzień Dobry”, nie spotkał się - mimo nakładu 300 tysięcy egzemplarzy ${ }^{10}-\mathrm{z}$ bezpośrednią rynkową reakcją Agory. Rok później, kiedy towarzyszy mu już „Metropol” (co gorsza nie tygodnik, a dziennik o średnim nakładzie ponad 180 tysięcy egzemplarzy), zaś we Wrocławiu pojawia się wydawany przez Polskapresse tytułu „Nasze Miasto” (90 tysięcy egz.), Grupa nie może sobie pozwolić na dalsze lekceważenie zagrożenia. Odpowiada wprowadzając na rynki Warszawy i Wrocławia własny bezpłatny tytuł „Metro” (początkowo średni nakład zaledwie 58 tysięcy), zaś w Łodzi i Gdańsku bezpłatne gazety codzienne z lokalnymi informacjami i ogłoszeniami („Bezpłatna Gazeta Wyborcza Łódź” - około 21 tysięcy, „Bezpłatna Gazeta Wyborcza Trójmiasto" - niecałe 16 tysięcy). Nakłady tych tytułów sprawiają wrażenie, jakby jednym z założeń powyższego przedsięwzięcia było przetestowanie reakcji rynku, przy zminimalizowanych nakładach własnych. Zapewne wpływ na to mają również informacje o wcześniejszych doświadczeniach prasy bezpłatnej za granica, gdzie w szeregu miastach nie była ona w stanie pozyskać wystarczającej liczby reklamodawców i generowała straty. Jej dystrybucję niejednokrotnie kontynuowano jedynie w celu blokowania konkurentów.

Daleko bardziej zdecydowany charakter ma zakup w kwietniu tegoż roku spółki City Magazine Sp. z o.o. z jej bezpłatnym miesięcznikiem o tym samym tytule. Nowy wydawca szybko rozszerza jego zasięg z 4 do 7 miast i zwiększa nakład do 150 tys. egzemplarzy.

10 Dwa lata później będzie to już ponad 700 tysięcy. 
W 2001 roku skonsolidowany raport finansowy Grupy nadal obejmuje wyłącznie Agorę S.A. i Agorę Poligrafię Sp. z o.o. Tej drugiej (bez względu na wielkość obrotów) nie sposób byłoby wyłączyć z konsolidacji bez istotnego zniekształcenia danych Raportu Rocznego - pełni ona bowiem niemal wyłącznie rolę usługową wobec Agory S.A., operując na wydzierżawionym od niej sprzęcie i wykonując dla niej usługi poligraficzne. Fakt, że reszta portfela Grupy wciąż nie podlega konsolidacji z powodu niespełniania warunku istotności określonego w zasadach polskiej księgowości, okazuje się w tym okresie bardzo korzystny dla jej obrazu zewnętrznego. W przeciwnym przypadku skonsolidowany wynik netto uległby pogorszeniu o straty w wysokości:

- Projekt Internet - 18,2 mln zt;

- Centrum Handlu Internetowego Sp. z o.o. - 4,0 mln zł (zawiązana rezerwa na udziały w $\mathrm{CHI}$ );

- City Magazine - 1,0 mln zł;

- Metro - 0,1 mln zł;

- działalność radiowa - 10,5 mln zł;

- TOK FM - 4,08 mln zł (strata proporcjonalna przypadająca na posiadany pakiet $41,6 \%$ udziałów).

Wszystkie powyższe przedsięwzięcia zaplanowano przy założeniu długiego horyzontu czasowego, bądź też zostały wymuszone przez posunięcia konkurencji. W 2001 roku, przy istniejącej kondycji otoczenia gospodarczego, stanowią istotne obciążenie dla Grupy, będąc dodatkowym argumentem na rzecz wdrożenia programu selektywnego cięcia wydatków.

W połowie roku, po dokonaniu analizy pozycji kosztowych, zarząd Agory podejmuje decyzję o rozpoczęciu cięć kosztów operacyjnych. W celu zahamowania wzrostu kosztów zatrudnienia zamrożeniu ulegają płace. Kolejnym, niezbędnym krokiem okazuje się decyzja o stopniowym zwolnieniu około 5\% wszystkich zatrudnionych. Konsekwencją - oprócz bieżących wydatków z tytułu odpraw - jest konieczność zawiązania rezerwy na 2002 rok na koszty zwolnień grupowych (1,5 mln zł). W dużym stopniu udaje się wyhamować wzrost kosztów z tytułu wynagrodzeń i świadczeń na rzecz pracowników (wzrost o 6,8\% w 2001 roku wobec 28,6\% rok wcześniej).

Na sytuację finansową Agory wywiera wpływ splot szeregu wydarzeń finansowych wewnętrznych i zewnętrznych. Grupa zmuszona jest wycofać się z zawartych w 2000 roku kontraktów terminowych na zakup euro po stałym kursie (znacznie odbiega on od bieżących notowań), ponosząc 
w całym 2001 roku koszty finansowe w wysokości 26,1 mln zł (wobec $8,5 \mathrm{mln}$ zł rok wcześniej). Poważne obciążenie stanowią inwestycje majątkowe (210,9 mln zł), w tym wydatki na budowę nowej siedziby (94 mln zł). Rachunek strat i zysków udaje się podreperować wyjściem z inwestycji w Telewizyjnej Korporacji Partycypacyjnej S.A. - Agora przenosi posiadany pakiet akcji na Cox Poland Investments, Inc. regulując nim zobowiązania z tytułu pożyczki udzielonej przez Cox’a w 1997 roku. Łączny wpływ transakcji zbycia akcji TKP zapewnia Grupie zysk netto w wysokości blisko $102 \mathrm{mln}$ zł.

Bilans 2001 roku nie wypada zbyt korzystnie z punktu widzenia założonej strategii. W przypadku projektów świeżo włączonych do portfela negatywny wpływ otoczenia gospodarczego opóźnia ich integrację i podnosi jej koszty. Wiele posunięć sprawia wrażenie spóźnionych z różnym skutkiem usiłują dogonić wydarzenia. Brak jest fuzji lub przejęć o strategicznym znaczeniu dla perspektyw rozwojowych Agory, mogących w przewidywalnym czasie znacząco zmniejszyć strukturalny brak równowagi między pozycją „Gazety” i reszty Grupy. Jasnym punktem wśród działań porządkujących pozostaje sfera poligrafii i kontynuowanych w niej konsekwentnych działań zwiększających potencjał drukarski. Osiagnięcie wystarczających mocy produkcyjnych przez własną nowoczesną bazę poligraficzną pozwala obniżyć koszty druku zewnętrznego o 40\%. Zakończony pierwszy etap budowy nowej siedziby z pewnością cieszy zarząd i pracowników Agory. Na razie jednak oznacza duże obciążenie finansowe dla firmy.

W dynamicznie sformułowanym Liście do akcjonariuszy dołączonym do Raportu Rocznego 2001 zarząd Agory - pragnąc upewnić inwestorów co do jasno nakreślonej i konsekwentnie realizowanej linii rozwoju Grupy ogłasza bardzo ambitną strategię inwestycyjną na 2002 rok, bazującą na:

- analizie rynku możliwości inwestycyjnych w Polsce i regionie (Węgry, Czechy, Słowacja, Bułgaria, Rumunia, kraje bałtyckie) pod kątem włączania do obecnego portfela nowych przedsięwzięć;

- polityce otwartych drzwi dla banków inwestycyjnych (włączenie ich do poszukiwania nowych przedsięwzięć i udział w budowaniu portfela transakcji „,w toku”) - hasło: ,...Będziemy pracować z każdym, kto naprowadzi nas na interesującą transakcję [...]"11;

11 List do akcjonariuszy prezesa zarzqdu Agory S.A., „,Raport Roczny 2001” (Warszawa, 2002 r.). 
- wykorzystaniu okresu recesji na rynku mediów na fuzje i przejęcia hasło: ,...Zamierzamy zdyskontować naszą siłę finansową i wykorzystać okres recesji w sektorze mediów dokonując fuzji i przejęć, zanim trudny czas dobiegnie końca [...]"12;

- skutecznym zintegrowaniu nowych przedsięwzięć i poprawie ich wyników, porządkowaniu dotychczasowego portfela przedsięwzięć (w tym sprzedaży udziałów mniejszościowych) - hasło: ,...Potem przekształcimy ten atrakcyjny zbiór rozmaitych przedsięwzięć, które zamierzamy nabyć, w jedną spółkę ze spójną multimedialną strategią [...]"13;

- przygotowaniu się do zakupu ogólnopolskiej stacji telewizyjnej.

Analizując sytuację w sektorze pod kątem swojej strategii na 2002 rok Agora szuka odpowiedzi na pytanie: czy recesja jest jedynie zagrożeniem, a może jest wręcz szansą?

Przygotowując swój przyszły program Grupa działa w warunkach dodatkowej presji. Pamiętajmy, że Agora - opracowując strategię na 2002 rok - jest w trakcie pierwszego w swej historii intensywnego programu oszczędnościowego, kończy co prawda rok bilansowy „na plusie” (także w odniesieniu do średnich wyników uzyskanych przez cały sektor), ale w nastroju dalekim od euforii typowej dla swojego wcześniejszego żywiołowego rozwoju. Inaczej mówiąc, potrzebuje nowej recepty na sukces. Zwracając uwagę na dojrzewanie rynku dostrzega konieczność podjęcia strategicznej reakcji. Oznacza to m.in. zmianę jakości analizy kosztów w celu wyeliminowania pozycji nierentownych.

Na bazie powyższych uwarunkowań Grupa decyduje się przyjąć klasyczną strategię agresywną, opartą na maksymalnym wykorzystaniu efektu synergii występującego między silnymi stronami firmy i szansami generowanymi przez otoczenie. Definiuje recesję jako szansę (zdając sobie oczywiście sprawę z tego, że błędne jej odczytanie i brak konsekwencji w wykorzystaniu przekształcić ją może w każdej chwili w olbrzymie zagrożenie). Jako bodaj jedyny z liderów sektora mediów oznajmia wszem i wobec: czujemy się silni, okres recesji otwiera przed nami nowe możliwości, nowe horyzonty rozwoju. Dla polskich przedsiębiorstw to novum klasyczną odpowiedzią na recesję jest strategia konserwatywna (maksymalne wykorzystanie wewnętrznego potencjału firmy w celu zminimalizowania negatywnego wpływu otoczenia) lub wręcz defensywna (walka

12 Agora u progu trzeciego millenium, „Raport Roczny 2001” (Warszawa, 2002 r.).

13 Ibidem. 
o przetrwanie, minimalizowanie wewnętrznych słabości i zagrożeń zewnętrznych). Dla typowego zarządu firmy recesja jest zagrożeniem, a nie szansą rozwoju i poprawy pozycji rynkowej (kosztem innych graczy, myślących raczej o przetrwaniu, a nie działaniach odwetowych, nie mówiąc o ekspansji).

Ogłaszając kontynuację ambitnych planów inwestycyjnych Agora zapewnia akcjonariuszy, że zdaje sobie sprawę z potencjalnych konsekwencji nieprzemyślanych, chaotycznych działań. Zaczynając od A (kupujemy), recytuje cały (?) alfabet do końca: integrujemy zakupy, poprawiamy ich wyniki, przygotowujemy kadrę menedżerską do nowych wyzwań ${ }^{14}$.

Jednocześnie obecnym i potencjalnym udziałowcom zostają przekazane sygnały „chłodzące”:

- każdy zakup wymagać będzie czasu i inwestycji, aby mógł zrealizować swój potencjał rozwojowy;

- rozszerzenie portfela o nowe przedsięwzięcia odbije się na krótkookresowych wynikach finansowych (elegancko to formułując ,...niektóre akwizycje mogą początkowo rozwodnić wyniki operacyjne"15);

- w warunkach recesji oczekiwany jest niewielki spadek przychodów i utrzymanie marży EBITDA na poziomie 2001 roku;

- ewentualne wejście w życie nowelizacji ustawy o radiofonii i telewizji w kształcie ograniczającym tzw. koncentrację kapitału w mediach (czyli poziomą konsolidację rynku medialnego $\mathrm{w}$ Polsce) będzie miało istotny, długofalowy wpływ na realizację przyjętej strategii.

Odzwierciedlenie powyższych sygnałów znajdujemy w założeniach budżetu Agory na 2002 rok. Nie przewidziano okresowych podwyżek wynagrodzeń. Założona zostaje dalsza redukcja wolumenu produkcji i ścisła kontrola kosztów na wszystkich poziomach operacyjnych. Z zakresu planowanych selektywnych cięć wydatków z góry wyłączone są jedynie ,...koszty kluczowe dla utrzymania pozycji rynkowej, dalszego rozwoju i realizacji strategii Agory [...]"16. W Liście do akcjonariuszy z kwietnia 2002 roku (kiedy znane już były wyniki I kwartału) zarząd - bojąc się po-

14 Założyć wypada, że użyte w Liście do akcjonariuszy z kwietnia 2002 roku sformułowanie „,przygotowanie kadry menedżerskiej do nowych wyzwań" dotyczy dłuższego horyzontu czasowego - bo do wyzwań wynikających ze strategii na 2002 rok kadra winna już być od dawna przygotowana.

15 List do akcjonariuszy Prezesa Zarzqdu Agory S.A., „Raport Roczny 2001” (Warszawa, 2002 r.)

16 Komentarz zarządu do „Raportu Rocznego” za 2001 rok. 
wtórzyć nadmiernie optymistyczne założenia z ubiegłorocznej strategii ocenia bieżący rynek reklamy jako stagnacyjny, bez szans na odbicie przed jego końcem. Liczy się z niewielkim spadkiem przychodów Grupy.

Implikacje nowelizacji ustawy medialnej w kształcie niekorzystnym dla Grupy znajdują swoje odbicie w planach aktywnego poszukiwania możliwości inwestycyjnych w krajach Europy Środkowej. Można je traktować zarówno jako formę amortyzatora inwestycyjnego, jak i sygnał o dostrzeganiu przez kierownictwo Agory stopniowego „wyczerpywania się" polskiego rynku medialnego w sensie ,tanich” inwestycji o relatywnie krótkim czasie zwrotu - na korzyść bardziej efektywnych fuzji i przejęć w krajach regionu (gdzie potencjał posiadany przez Agorę pozwoli jej, w przypadku dostatecznie wczesnego i zdecydowanego zaangażowania, dołączyć do grupy głównych graczy w lokalnym sektorze medialnym a tym samym przejąć istotną część rynku reklamy).

\section{Agora 2002 - „trzymamy się strategii”}

Zgodnie z przewidywaniami 2002 rok okazuje się kolejnym rokiem pogłębiającej się recesji na rynku reklamy w Polsce. Wydatki spadają o $11 \%$, przy czym najboleśniej odczuwa to segment prasowy $(-19,1 \%)$, w tym dzienniki (-22,2\%). Wyjątkowo agresywnie walczy o rynek telewizja, przechodząc ze sprzedaży czasu antenowego na sprzedaż widowni i prowadząc bezpardonową wojnę rabatową ${ }^{17}$.

Maleje również liczba sprzedawanych egzemplarzy prasy codziennej (-6\%), szczególnie w grupie ogólnokrajowych dzienników opiniotwórczych $(-9,8 \%)^{18}$.

Problemy rynkowe nie omijają „Gazety Wyborczej”. Jej średni nakład sprzedany spada o $8,4 \%$, przychody ze sprzedaży ogłoszeń - o 20,6\%. Sa to wyniki niewiele lepsze od średniej krajowej. Pocieszający jest jedynie równoległy spadek kosztu papieru i druku „Gazety” (-19,3\%), związany w pierwszym rzędzie ze zmniejszeniem wolumenu produkcji, spadkiem cen papieru oraz działaniami oszczędnościowymi (spadek zatrudnienia, wykorzystanie części mocy w drukarniach na cele usług zewnętrznych).

17 W ocenie Agory realne wpływy stacji telewizyjnych były w 2002 roku niższe o około $65 \%$ od danych cennikowych.

18 Dane ZKDP za 2002 rok. 
Zwraca uwage pewne zawahanie w strategii Grupy wobec segmentu prasy bezpłatnej. Średni jednorazowy nakład „Metra”, rozdawanego w Warszawie, Katowicach i Wrocławiu, wynosi pod koniec roku już blisko 300 tysięcy egzemplarzy. Przy rocznych przychodach rzędu $3 \mathrm{mln}$ zł tytuł generuje jednak, po raz kolejny, stratę. W konsekwencji zapada decyzja o zawieszeniu (od stycznia 2003 roku) wydawania „Metra” we Wrocławiu.

Już nawet nie wieloznaczne „zawieszenie”, ale wprost „,zakończenie” wydawania ma miejsce w przypadku „Bezpłatnej Gazety Wyborczej”, której zasięg w międzyczasie zwiększono do 5 miast (Łódź, Trójmiasto, Kraków, Poznań, Szczecin). Ten krok tłumaczony jest ,...otwarciem możliwości działań marketingowych «Gazety Wyborczej» na sieci nośników reklamy zewnętrznej [...]"19.

W 2002 roku Agora „trzyma się strategii”, intensywnie inwestując. W kwietniu za 73,8 mln zł nabywa firmę Prószyński i S-ka - Czasopisma Sp. z o.o (wraz z jej 12 czasopismami). Kolejne 168,4 mln zł kosztuje zakup, pod koniec roku, akcji spółki reklamy zewnętrznej Art Marketing Syndicate S.A. (AMS S.A.), wreszcie 155,8 mln zł pochłaniają wydatki na niefinansowe aktywa trwałe. Z tej ostatniej kwoty większość (108 mln) stanowią inwestycje w bazę Grupy ${ }^{20}$, pozostała część to zakup praw do 4 tytułów magazynów motocyklowych $(4,2 \mathrm{mln})$, inwestycje poligraficzne $(27,4 \mathrm{mln})$ i projekt Internet $(2,3 \mathrm{mln})$. Zaciagnięty zostaje kredyt inwestycyjny w kwocie 139,5 mln zł.

Burzliwy przebieg ma inwestycja Agory w AMS S.A. Do dnia 30 września Grupa wchodzi w posiadanie 16,63\% kapitału zakładowego spółki (prawo do 29,92\% głosów). W IV kwartale - w wyniku dwóch kolejnych wezwań na sprzedaż akcji - zwiększa udział do 99,48\%, konsolidując nabytek z resztą swojego koncernu. Tymczasem jednak przychody AMS w 2002 roku (102,8 mln zł) spadają o 41\% w stosunku do roku poprzedniego. Spółka traci część nośników (kilkunastomiesięczne opóźnienia w płaceniu czynszów), odchodzi niemal cały zespół handlowców odpowiedzialny za sprzedaż nośników typu citylight. Konkurencja wykorzystuje sprzyjające okoliczności związane z rozprężeniem organizacyjnym w trakcie zmiany właściciela i częściowo wypiera AMS z rynku.

19 Komentarz Zarządu do „Raportu Rocznego” za 2002 rok.

20 Budowa siedziby Agory - 81,3 mln zł, zakup działki pod jej rozbudowę 10,5 $\mathrm{mln}$, inwestycje komputerowo-telekomunikacyjne - 16,2 mln. 
Dodatkowo dokłada się ogólny spadek sprzedaży w segmencie outdoor $(-9,5 \%)$.

Agora rozpoczyna długotrwałą i kosztowną odbudowę grupy AMS. Likwiduje spółki zależne AMS nie rokujące jej zdaniem nadziei na odzyskanie rentowności (stale deficytowe). Reorganizuje dział sprzedaży, zmieniając jego strukturę i przenosząc go do biura w Warszawie. Integracji ulegają służby handlowe AMS S.A. i jej spółki zależnej Adpol Sp. z o.o. Ma miejsce przegląd polityki handlowej obejmujący zmiany systemu cen i rabatów. Rozpoczyna się cięcie kosztów i restrukturyzacja zobowiązań finansowych.

W 2002 roku udział radiostacji lokalnych Agory w rynku reklamy radiowej wzrasta o $2 \%$ (do $12,2 \%$ ). Nie jest to jednak zasługą ich rosnącej efektywności w pozyskiwaniu reklam, a jedynie rozbudowaniu grupy o kolejne 9 rozgłośni. Nowe stacje wymagają - z czego zarząd Grupy zdaje sobie sprawę - ,...poważnych zmian organizacyjnych i programowych (uruchomienie nowych formatów) oraz nakładów na badania i promocję [...]"21. Co gorsza, wydatki na reklamę radiową w skali całego kraju ciągle maleją, szczególnie w segmencie radiostacji lokalnych (o 13,8\%). W tych warunkach Agora nie jest w stanie uniknąć straty netto w wysokości 11,4 mln zł (przy 43,4 mln zł przychodu), o 9,4 mln zł więcej niż rok wcześniej. Nie mniejsze problemy istnieją w ponadregionalnym TOK FM, gdzie przychody ze sprzedaży spadają o blisko $33 \%$, a strata netto osiąga 4,9 $\mathrm{mln} \mathrm{zl}$.

2002 rok Agora zamyka przychodami netto w wysokości 785,3 mln zł. Odnotowany tym samym wzrost o $1,1 \%$ jest jednak wyłącznie efektem zabiegu księgowego. Od kwietnia przedmiotem konsolidacji stają się wyniki finansowe grupy czasopism, od IV kwartału metodą pełną konsolidowana jest grupa AMS S.A. ${ }^{22}$ Od tego roku sprawozdanie Agory obejmuje również wyniki 21 spółek zależnych i stowarzyszonych działających w segmencie radiowym. Skonsolidowany rachunek zysków i strat nie uwzględniający powyższych pozycji zamknąłby się przychodami na poziomie 683,5 mln zł, wykazując spadek o 12\% w stosunku do roku ubiegłego.

Podobnej weryfikacji wymaga informacja o kosztach operacyjnych (liczonych bez amortyzacji), rosnących w 2002 roku o blisko $10 \%$. Oczyszczenie rachunku z wpływu finansowego nowych projektów prze-

21 Komentarz Zarządu do „Raportu Rocznego” za 2002 rok.

22 W III kwartale wycena dokonywana była metodą praw własności ze względu na reprezentowanie tylko $16,63 \%$ kapitału zakładowego spółki. 
kształci ten wzrost w spadek o 7,6\%. W jednostkach bezwzględnych oznacza to różnicę w ujęciu skonsolidowanym rzędu $100 \mathrm{mln}$ zł, „wniesioną w posagu" przez nowe projekty.

Słowa „trzymamy się strategii” stanowią myśl przewodnią Listu do Akcjonariuszy podsumowującego dokonania Grupy w 2002 roku. Zarząd stara się natchnąc ich optymizmem, przedstawiając swoje posunięcia inwestycyjne i restrukturyzacyjne w możliwie jasnych barwach: „,..Poczyniliśmy [...] spore postępy w rozwijaniu Agory w firmę multimedialną i dzięki temu jesteśmy dobrze przygotowani do tego, aby wykorzystać odbicie na rynku reklamy [...]”. I dalej, ,...co prawda wpływy z „Gazety” spadły, jednak konsolidacja radia, magazynów i AMS spowodowała, że całkowite przychody Agory wzrosły [...]". Ton tego stwierdzenia ma być optymistyczny, ale - po pierwsze - konsolidacja to jedynie przesunięcie księgowe, a - po drugie - wzrost całkowitych przychodów może być powodem do radości, jeżeli generuje dodatkowy zysk. Póki co, jak możemy przeczytać w kolejnym zdaniu Listu ,...przejęte przedsięwzięcia wpłynęły negatywnie na wyniki operacyjne grupy [...]”. Czyli z radością wypada się jeszcze wstrzymać.

Podsumowanie roku, dokonane przez zarząd Agory w formie porównania poszczególnych założeń strategii z ich realizacją zostanie w całkowicie odmienny sposób odczytane przez entuzjastę koncernu i jego surowego krytyka. Pierwszy z nich pozytywnie oceni przyjęty i zrealizowany kolejny etap strategii rozwoju poprzez przejęcia na rynku mediów - wejście na rynki reklamy zewnętrznej i czasopism oraz zwiększenie skali działalności radiowej. Krytyk, zapewne nie negując samej idei rozwoju poprzez przejęcia, zwróci uwagę na nie zawsze zadowalającąjakość nowych i rozbudowywanych projektów oraz na niesione przez nie zagrożenia. Jako kluczową (choć nie zawinioną) porażkę oceni niezrealizowane wejście na rynek telewizji ogólnopolskiej - przedsięwzięcie, które jako jedyne, w przeciwieństwie do pozostałych wdrażanych w ramach obecnej strategii, byłoby w stanie zapewnić Agorze przeciwwagę dla niebezpiecznego wspierania się na jednym filarze w postaci „Gazety Wyborczej”.

Podobnie przedstawiać się będzie ocena elementu strategii związanego z utrzymaniem rentowności i płynności Grupy. Pozytywny recenzent zauważy, przykładowo, wskazany przez zarząd fakt „,zwiększenia przychodów grupy radiowej”, jak również „umocnienie pozycji reklamowej i czytelniczej w Warszawie poprzez wejście na rynek prasy bezpłatnej”. Krytyk wytknie z miejsca koszty związane z inwestycją w radiostacje regionalne i poważne obawy co do ich potencjału rozwojowego. Zauważy, 
że przedsięwzięcie to, realizowane od 1996 roku (ponad 6 lat), nadal nie wykazuje cech dojrzałości. Równie chłodno potraktuje sukces w postaci wejścia na rynek warszawskiej prasy bezpłatnej, oceniając go jako drugorzędny dla koncernu mającego ambicje bycia multimedialnym liderem w skali ogólnopolskiej.

Istotnym, może nawet dominującym elementem Listu są okoliczności i konsekwencje forsowanej nowelizacji ustawy o radiofonii i telewizji kluczowej z punktu widzenia możliwości rozwoju i konsolidacji Agory w nadchodzących latach. Fakt, że koncern stał się, wbrew swoim intencjom, jawnym uczestnikiem tej batalii, może i zapewne będzie mieć istotny wpływ na jego przyszłą pozycję i strategię.

W Komentarzu do „Raportu Rocznego” za 2002 rok zarząd Grupy ocenia perspektywy Agory na kolejne 12 miesięcy. Przy założonym 2,5\% wzroście PKB i kilkuprocentowym spadku wydatków na reklamę, całkowite przychody Grupy (uwzględniające konsolidację nowych przedsięwzięć ${ }^{23}$ ) wzrosnąć mają o ponad $10 \%$. Zarząd deklaruje zarazem „skrupulatną kontrolę kosztów na każdym poziomie operacyjnym” i dalsze zamrożenie podwyżek płac.

Mimo zapowiedzi o trzymaniu się strategii wyraźnie zmienia się w porównaniu z ubiegłorocznym - ton wypowiedzi zarządu. Trudniej odnaleźć hasła o polityce otwartych drzwi dla banków inwestycyjnych, dyskontowaniu siły finansowej, wykorzystywaniu okresu recesji do fuzji i przejęć (,zanim trudny czas dobiegnie końca”). Wydaje się, że wydatki inwestycyjne i perturbacje przy porządkowaniu konsolidowanych projektów zaczynają, w warunkach recesji, coraz mocniej ciążyć Grupie.

Ale to dopiero początek kolejnej fali problemów. W ciągu najbliższych miesięcy - za sprawą jednego nowego tabloidu - pod znakiem zapytania stanie cała dotychczasowa strategia przekształcania Agory w firmę multimedialną.

\section{Zachwiane status quo}

Przez okres medialnej prosperity lat 90-tych polski rynek prasowy ograniczał się niemal wyłącznie do przetasowań przy udziale firm już obecnych na rynku. Główni zagraniczni gracze (Passauer i Orkla - segment dzienników, Bauer - czasopism) pojawili się w początku dekady i od

23 Co oczywiście „okupione” zostanie zwiększoną bazą kosztową. 
tego czasu stopniowo budowali pozycję, przejmując krok po kroku lokalnych konkurentów, między sobą pozostając w stanie rozejmu.

W ostatnim kwartale 2001 roku wydawało się, że istniejący układ sił w magazynach opiniotwórczych ulegnie zasadniczemu zachwianiu - za sprawą Springera i nowego, agresywnie reklamowanego tygodnika „Newsweek Polska"24. Jego start w nakładzie 300 tysięcy egzemplarzy okazał się bowiem tak udany, że dopiero dodruk kolejnych 200 tysięcy zaspokoił popyt rynkowy. Sprzedany nakład kolejnych edycji regularnie przekraczał 300 tysięcy (zamiast zakładanych w planie niecałych 200), od początku mając nadspodziewanie wysokie obłożenie reklamami.

W poczuciu zagrożenia (mimo deklaracji Springera, że pragnie on poszerzyć rynek czytelników czasopism społeczno-gospodarczych, a nie odbierać go już obecnym tygodnikom o tym profilu) wydawcy „Polityki” i „Wprost” przeprowadzili szereg zmian redakcyjnych i poligraficznych. Z dobrym skutkiem - gdyż uatrakcyjniły szatę graficzną i formułę swoich produktów. W pewnym sensie niepotrzebnie - gdyż „Newsweek”, ze swoją sugestywną infografiką i dynamicznymi, krótkimi artykułami rzeczywiście, jak się wydaje, powiększył segment ${ }^{25}$, jednocześnie uzyskując nadspodziewanie wysoki stopień duplikacji (zarówno czytelników, jak i reklamodawców) z obu głównymi konkurentami. Rynek wykazał, że nadal dopiero dojrzewa i posiada jeszcze pewien zasób niewykorzystanej chłonności.

22 października 2003 roku Springer proponuje polskiemu rynkowi prasowemu ,powtórkę z rozrywki”, tym razem w segmencie dzienników ogólnopolskich. Wprowadza na rynek „Fakt”. W wywiadzie dla agencji Reuters Andreas Wiele, członek zarządu ASV oświadcza, że celem koncernu jest sprzedaż na początku 200 tysięcy egzemplarzy i zwiększenie jej do poziomu 300 tysięcy $w$ ciagu najbliższych $3-5$ lat $^{26}$.

Już sama zapowiedź ukazania się nowego dziennika elektryzuje wydawców „Gazety Wyborczej”, „Super Expressu” i „Rzeczpospolitej”. Ko-

24 Reklamy spięte nośnym hasłem: „Tydzień zaczyna się od Newsweeka” (z dodatkową aluzją do konkurencyjnej „Polityki” - „Newsweek” dociera do kiosków w poniedziałek, „Polityka” dopiero w środę).

25 Głównie o grupę młodych ludzi w wieku 15-25 lat. Okazało się to rozszerzeniem wobec planowanej grupy celowej: wszyscy 25-49, osoby z wyższym wykształceniem, mieszkańcy dużych miast.

${ }^{26}$ Według danych ZKDP średni nakład sprzedany pierwszych dziewięciu wydań wyniósł 342 tysiące egzemplarzy. 
lejność ich wymienienia nie jest przypadkowa i oddaje skalę i siłę reakcji. Najsłabszą ze strony „Rzeczpospolitej”, co wydaje się całkowicie zrozumiałe ze względu na specyfikę tego dziennika wyraźnie ukierunkowanego na „poważne” tematy polityczne i gospodarcze, przywiązującego dużą wagę do poziomu merytorycznego zamieszczanych analiz. Znacznie silniejszą - „Super Expressu”, co również nie budzi wątpliwości ze względu na podobne pozycjonowanie jak „Faktu”. I wreszcie najsilniejszą- „Gazety Wyborczej”, sprawiającą wrażenie, że konkurent natrafił na szczególnie czuły jej punkt. W tym miejscu pojawia się już problem $\mathrm{z}$ w pełni przekonującym uzasadnieniem nieproporcjonalnie (jak by się wydawało) silnej reakcji. „Gazeta” jest dziennikiem opiniotwórczym (z dużymi ambicjami), a „Fakt” to bez wątpienia klasyczny tabloid.

Tabloid, zwany potocznie dziennikiem bulwarowym (a często jeszcze mniej kurtuazyjnie) stanowi zaprzeczenie poważnej prasy informacyjnej. Bazuje na sensacji przekazywanej w emocjonalnej formie, tworzy niespokojne, zaskakujące rozwiązania graficzne. Podczas gdy dziennik opiniotwórczy służy czytelnikom do uzyskiwania informacji o bieżących wydarzeniach i wyrabiania sobie opinii na tematy polityczne, społeczno-kulturalne i gospodarcze, przywiązuje dużą wagę do analiz, komentarzy ekspertów i polityków - tabloid również żyje z pozyskanych informacji, ale „wyciska” z nich niemal wyłącznie skandale, sensacje i rozrywkę. Poważne oceny i analizy pozostają poza sferą jego zainteresowań. Stały czytelnik „Gazety Wyborczej” nie zrezygnuje z niej dla „Faktu”. Zbyt odmienne jest pozycjonowanie obu wydawnictw.

A zatem element zagrożenia w postaci substytucji „Gazety Wyborczej” i „Faktu” nie do końca przekonuje. Oczywiście w warunkach kurczącego się rynku czytelniczego zawsze istnieje obawa, że część osób, którym spodoba się formuła „Faktu” - a kupią go zwabione reklamą i konkursem z nagrodami, nie mówiąc o atrakcyjnej cenie 1 zł - odejdzie od „Gazety” z powodu ograniczonego budżetu domowego przeznaczonego na prasę. Trudno jednak przypuszczać, że nastąpią w związku z tym zasadnicze przetasowania.

Kolejny element zagrożenia to utrata istotnej części budżetów reklamodawców. Oczywiście, każde nowe wydawnictwo pozyskuje jakieś ogłoszenia. Ponieważ jednak „Gazeta” i „Fakt” są inaczej pozycjonowane, zainteresowany „Faktem” reklamodawca raczej ulokuje tam dodatkowe ogłoszenie, niż dokona substytucji. Co więcej, szereg uczestników rynku reklamowego w ogóle omija tabloidy. Potężny niemiecki bulwarowy „Bild” (notabene również własność koncernu Springera) ze sprzedaży 
ogłoszeń uzyskuje średnio zaledwie 40\% swoich przychodów. „Gazeta Wyborcza" - blisko dwa razy tyle.

Mimo to Agora postanawia przekazać Springerowi jednoznaczny sygnał, że posiada i w pełni wykorzysta swój potencjał do uniemożliwienia mu odniesienia spodziewanego sukcesu swoim kosztem:

- uruchamia preliminowany na kilkadziesiąt milionów złotych budżet reklamowy służący obronie pozycji „Gazety Wyborczej”, jednocześnie uatrakcyjniając jej formułę;

- informuje, ku powszechnemu zaskoczeniu, że przystępuje do prac nad wprowadzeniem na rynek własnego tabloidu.

Obudowując od pewnego czasu „Gazetę”, krok po kroku, szeregiem bezpłatnych dodatków („Wysokie Obcasy”, „Wysokie Obroty”, „Magazyn Gazety”, „Gazeta Telewizyjna”, „Komiksowo”, „W Kratkę”) ${ }^{27}$ oraz rozbudowując $\mathrm{w}$ wydaniu głównym elementy informacyjne o charakterze śledczym (tropienie nieprawidłowości, nonsensów legislacyjnych i ekonomicznych, tzw. afer) Agora konsekwentnie dąży do zrównoważenia mocnych stron tabloidów.

Równolegle, w 2003 roku, w odpowiedzi na posunięcia konkurenta, ogłasza projekt inwestycji w ogólnopolski tabloid. W sensie finansowym byłby on przedsięwzięciem potężnym, ale - z czego Springer zdaje sobie sprawę - dla Agory potencjalnie wykonalnym ${ }^{28}$. Według danych Grupy na koniec 2002 roku posiadała ona ok. $50 \mathrm{mln}$ złotych wolnych środków własnych i dostępną linię kredytową w kwocie 500 mln zł (z której w 2002 roku wykorzystano niespełna $140 \mathrm{mln}$ ). Pytanie, na ile zamiar ten był traktowany przez Agorę jako przedsięwzięcie realne? Czy nie był od samego początku jedynie sygnałem rynkowym, a nie rzeczywistym projektem, nigdy nie wychodząc poza stadium co najwyżej prac studyjnych? Jeżeli miałby być faktycznie zrealizowany, wydaje się, że został zainicjowany zbyt późno (realne byłoby jego wejście dopiero kilka miesięcy po inauguracji „Faktu”). Dla trzeciego z kolei tabloidu - po „Super Expresie” i „Fakcie” - rynek mógłby okazać się zbyt płytki. Co najwyżej byłby tzw.

27 Część z nich, w atrakcyjnej szacie graficznej („Wysokie Obcasy”, „Wysokie Obroty”) stanowi dość kosztowne przedsięwzięcie (tak jak „Magazyn” i „Gazeta Telewizyjna") - wymaga podjęcia decyzji zlecania druku (okładek lub całości dodatków) w drukarniach zewnętrznych dysponujących technologią druku piecowego.

28 Choć oznaczałby konieczność zarzucenia lub zminimalizowania innych projektów - o czym mowa w dalszej części opracowania. 
wojującą marką, służącą jako ostrzeżenie przed podejmowaniem przez konkurenta dalszych przedsięwzięć. Ale jakich?

Trudno oprzeć się wrażeniu, że wszystkie podejmowane przez Agorę działania służą nie tylko obronie bieżącej pozycji „Gazety Wyborczej”, ale - w jeszcze większym stopniu - są właśnie sygnałem na przyszłość wysłanym Springerowi. Albowiem Grupę chyba bardziej niepokoi jutrzejsza niż dzisiejsza wizja koegzystencji na rynku z tym konkurentem. Nawet, jeżeli będzie się ona odbywać w warunkach rosnącego popytu.

Dlaczego jednak największym problemem dla Agory stać się ma z czasem Springer, a nie Bauer, Verlagsgruppe Passau, Orkla czy też medialne koncerny z Francji, Anglii lub Włoch?

Wszystko wskazuje na to, że główni, ,zakorzenieni” gracze na polskim rynku prasowym - Bauer, Passau i Orkla - już dość dokładnie określili swoją pozycję i ambicje. Bauer, wyspecjalizowany w segmencie czasopism (przypomnijmy - 30 tytułów o łącznym nakładzie ok. 8,3 mln egzemplarzy), uzupełnia i modyfikuje swój portfel jedynie w ramach tego zakresu. Passau jest zainteresowane wyłącznie prasą lokalną i regionalną. Od tej zasady nie ma wyjątku, co jasno sprecyzował Franz Xaver Hirtreiter, zostając szefem koncernu. Passau (wówczas jeszcze Passauer Neue Presse), odkupując od Hersanta pakiet jego polskich tytułów, mógł przejąć również udziały w ogólnopolskiej „Rzeczpospolitej”. Nie sfinalizował tego elementu transakcji. Akcje „Rzeczpospolitej” objęła Orkla, ale cała reszta jej stanu posiadania to jedynie dzienniki regionalne - wraz z gazetami koncernu Passau niemal całkowicie pokrywające mapę Polski.

Do czasu ostatnich posunięć Springera te puzle tworzą doskonale czytelny, stabilny obraz. Gdy jednak do nich dochodzi, wszyscy główni gracze na naszym rynku prasowym (z Agorą na czele) biorą się za „odrabianie lekcji”. Wyciągając wnioski z każdego ruchu Grupy ASV (lub samej zapowiedzi), zaczynają modyfikować wiele elementów swoich strategii ,pod Springera”.

Nietrudno zrozumieć, dlaczego. Axel Springer Verlag należy do najpotężniejszych koncernów prasowych w Europie. Ze sprzedażą o wartości niemal 2,8 mld euro jest największym wydawcą prasy w Niemczech. Stanowi bez wątpienia firmę „kompletną”, silnie i wszechstronnie umocowaną w branży medialnej (o czym dopiero marzy Agora). Organizacyjnie, merytorycznie i finansowo przygotowany do wejścia w każdy segment polskiego rynku prasowego hołduje zasadzie budowania kompletnych projektów mających za zadanie dotarcie do wszystkich rozpoznanych grup celowych. Dodatkowym zagrożeniem dla konkurencji jest chętnie 
stosowana przez Springera metoda kalkowania na obcych rynkach własnych popularnych wysokonakładowych tytułów, od lat wydawanych w Niemczech (co skraca początkowy etap inwestycji i obniża jej koszty).

Co gorsza (z punktu widzenia polskich wydawców), ASV jest wprost zmuszony poszukiwać nowych rynków zagranicznych. Od lat opóźnienie koncernu w tej dziedzinie - w porównaniu z pozycją konkurentów - jest wprost dramatyczne. W 2000 roku z zagranicznych operacji pochodzi zaledwie $15 \%$ wartości sprzedaży w ujęciu skonsolidowanym, z tego w dziale gazet $-8 \%$, książek - $12 \%$, mediów elektronicznych $-3 \%$. Sytuację ratują tylko czasopisma - $22 \%$ sprzedaży zapewniają projekty zagraniczne. Te nikłe wartości procentowe to zaledwie jeden z problemów. Springer zdaje sobie sprawę z faktu, że obecnie inwestowanie w dojrzałe, w pełni „zagospodarowane” przez konkurentów rynki Europy Zachodniej oznacza, obok nadmiernego ryzyka wynikającego z wysoko postawionych barier wejścia, także konieczność ponoszenia nieproporcjonalnie dużych nakładów. Jego projekty w Europie Zachodniej mają charakter „punktowy”: jak na przykład hiszpańskie wydawnictwa z zakresu architektury wnętrz oraz komputerów i gier komputerowych ${ }^{29}$ - czy też marginalna obecność w sąsiedniej Austrii ${ }^{30}$ i niewiele poważniejsza we Francji i Portugalii. Pozostaje zatem ekspansja na gorzej zorganizowanych, dojrzewających rynkach prasowych Europy Środkowo-Wschodniej. W tym w Polsce, gdzie Springer jest reprezentowany dopiero w niektórych segmentach $^{31}$. Aż prosi się o kolejne projekty, tym bardziej, że realne staje się stopniowe (choć powolne) ożywienie gospodarcze i wzrost konsumpcji indywidualnej po nieodległym przystąpieniu Polski do Unii.

W Raporcie Rocznym za 2002 rok prezes zarządu ASV Mathias Döpfner wśród celów strategicznych koncernu wymienia zarówno jego

29 Te pierwsze reprezentowane przez 3 tytuły o łącznym nakładzie ok. 320 tys. egzemplarzy, drugie zaś - wydawane co prawda w nakładzie ponad 460 tys. egzemplarzy, ale w rozbiciu aż na 8 tytułów, z których połowa nie osiaga jednorazowo 40 tys. egzemplarzy.

30 Większościowe udziały w jednej gazecie, „Tiroler Tageszeitung”, o średniej sprzedaży poniżej 90 tys. egzemplarzy.

31 W 2000 roku Grupa ASV ma znaczącą pozycję głównie w segmencie polskich czasopism, wydając 14 tytułów, o jednorazowej łącznej sprzedaży ponad 2,7 mln egzemplarzy. Filarami są magazyny kobiece „Pani Domu” i „Olivia” oraz magazyn motoryzacyjny „Auto Świat”. Do chwili obecnej prasę poważną reprezentują jedynie miesięcznik biznesu i finansów „Profit” oraz licencyjny tygodnik opinii „Newsweek Polska". 
rynkowe przywództwo w segmencie prasowym na obszarze niemieckojęzycznym, jak i umiędzynarodowienie tegoż segmentu. Czytelnie jest też sformułowana teza: ,...otwarcie szybko rosnących nowych rynków Europy Wschodniej ma priorytet $\mathrm{w}$ pierwszym etapie programu umiędzynarodowienia [koncernu - dop. JZ] [...]"32.

Już kilka miesięcy później, w październiku 2003 roku, strategia Springera po raz pierwszy stawia Grupę Agora i Grupę ASV naprzeciw siebie. $\mathrm{Na}$ polskim rynku prasowym pojawia się „Fakt”.

\section{Agora versus Springer}

Wkraczając w 2003 rok obaj konkurenci mają za sobą ciężki okres zmagania się ze skutkami recesji rynkowej.

W tym czasie oba rynki mediów, polski i niemiecki, nie zachwycają wynikami - choć drugi z nich odnotowuje już pierwsze sygnały wychodzenia z kryzysu. W przeciwieństwie do rynku reklamy w Polsce (spadek o dalsze $1,2 \% \mathrm{w}$ porównaniu $\mathrm{z}$ analogicznym okresem 2002 roku), w Niemczech notuje on symboliczny wzrost o $0,1 \%{ }^{33}$. Sprzedaż ogłoszeń w gazetach wzrasta przy tym o $8,3 \%$, w czasopismach nadal trwa regres $(-7,3 \%)$. W istniejących warunkach Springer, mimo że nie zachwyca wynikami operacyjnymi, równoważy spadek w dochodach z reklam (-28 mln euro) wzrostem wpływów ze sprzedaży nakładu gazet i czasopism (+29 mln euro). Nie oznacza to wcale braku problemów. „Stare” tytuły (na czele z „Bild'em” i „Die Welt”) ciągle tracą nakład sprzedany, a powstałe ubytki - zgodnie ze swoją strategią - koncern uzupełnia nowymi bezpłatnymi dodatkami i płatnymi magazynami, piętrząc bariery wejścia dla konkurencji. Jednocześnie Springer nie waha się podnieść ceny sprzedaży szeregu tytułów, co w połączeniu ze wzrostem wpływów z operacji zagranicznych (w tym udzielanych licencji wydawniczych) pozwala zbilansować spadek $\mathrm{w}$ dochodach $\mathrm{z}$ reklamy.

Zdecydowanie trudniejszą sytuację ma w tym czasie Agora nadal bazująca na jednym dominującym tytule. Tak jak Springer, musi funkcjonować $\mathrm{w}$ otoczeniu gospodarczym nadal pozostającym w złej kondycji.

32 Wstęp do „Raportu Zarządu” za 2002 rok.

33 Dane dotyczące rynku niemieckiego oparte na statystykach Nielsen Media Research. W przypadku obu krajów wszystkie porównania procentowe prezentują dynamikę I półrocza 2003 roku do I półrocza 2002 roku. 
W I półroczu 2003 roku wydatki na reklamę w dziennikach w Polsce są niższe o $10,7 \%$, co w równej mierze jest spowodowane kryzysem rynku reklamy, jak i presją rabatową, w pierwszym rzędzie wywołaną przez stacje telewizyjne ,podbierające” swoją polityką cenową reklamy z innych segmentów.

Przychody „Gazety Wyborczej” ze sprzedaży nakładu i reklam stanowią w tym czasie $70 \%$ przychodów całej Grupy ${ }^{34}$. Chociaż jej średnie dzienne rozpowszechnianie maleje o około 3\%, zaś wpływy ze sprzedaży o 2,5\%, dziennik pozostaje liderem na rynku czytelniczym w swoim segmencie. Cała Grupa wyraźnie jednak odczuwa blisko 12-procentowy spadek przychodów ze sprzedaży ogłoszeń w „Gazecie”.

Nadal brakuje wsparcia ze strony innych projektów wdrażanych przez Agorę. Kontynuując dotychczasową strategię Grupa stara się budować pozycję rynkową zakupionych $\mathrm{w}$ ostatnim okresie czasopism, tak, „,...aby w kolejnych latach możliwy był znaczący wzrost udziału w rynku reklamy [...]"35. Tymczasem jednak, w I półroczu 2003 roku, magazyny Agory generują przychody w wysokości zaledwie $37,8 \mathrm{mln}$ zł, przy kosztach operacyjnych (liczonych łącznie z kosztami reklamy) przekraczających $47 \mathrm{mln}$ zł. Pod presją uciekającego czasu koncern niemal równolegle wprowadza na rynek nowy miesięcznik motoryzacyjny „Auto+” (w lutym, w miejsce innego magazynu motoryzacyjnego), magazyn kobiecy „Poradnik Domowy” (w marcu - z nową makietą i logotypem), odświeżony miesięcznik „Wiedza i Życie” (w kwietniu - z nową makietą i logo, w zwiększonej objętości) i zmieniony miesięcznik „Dziecko” (czerwiec nowa makieta i logo, większy format, lepszy papier). Liczba wydań specjalnych wspierających te czasopisma może imponować, ale pójście tak szerokim frontem jest kosztowne i ryzykowne. Sama tylko kampania reklamowa pochłania $15 \mathrm{mln}$ zł. Co więcej, według nieoficjalnych informacji Agora przygotowuje projekt całkowicie nowego magazynu dla kobiet, przewidzianego do wprowadzenia na rynek w I połowie 2004 roku. Posunięcie co najmniej ryzykowne, gdyż segment ten - ceniony przez reklamodawców - zaliczany jest zarazem do najtrudniejszych i doskonale

34 A zatem ich udział szybko maleje (jeszcze w 2000 roku wynosił 95\%), ale jest to jedynie wynikiem zabiegu księgowego - włączenia do skonsolidowanego bilansu kolejnych przedsięwzięć (grupa radiowa i grupa AMS). Nie oznacza zarazem bardziej zrównoważonej struktury medialnej całej Grupy (konsolidowane projekty ciagle generują straty i trudno wyrokować na temat ich przyszłości).

${ }^{35}$ Komentarz zarządu do Raportu za pierwsze półrocze 2003 r. 
obsadzonych przez największych graczy rynku czasopism (z grupą Bauer na czele).

„Rozgrzebanych” tematów jest znacznie więcej. W tym samym okresie Agora prowadzi restrukturyzację zadłużenia zakupionej w ubiegłym roku spółki AMS S.A., spłacając jej krótkoterminowe kredyty bankowe i bony dłużne lub zastępując je własnymi długoterminowymi pożyczkami. Z pewnością korzystnie jest posiadać silną pozycję w sektorze reklamy zewnętrznej (a uzdrowiona grupa AMS może ją zapewnić), ale po $55 \mathrm{mln}$ zł pożyczek udzielonych do końca 2002 roku oznacza to dla Agory dalsze 10 mln zł wydanych w okresie styczeń-luty 2003 roku i konieczność objęcia w marcu nowej emisji za wkład pieniężny w wysokości kolejnych $30 \mathrm{mln} \mathrm{zf}^{36}$. Tymczasem jednak - mimo poniesionych nakładów - przychody Grupy ze sprzedaży reklamy zewnętrznej rosną w I półroczu 2003 roku w dość umiarkowanym tempie (do 55,7 mln zł, z 51,2 mln zł w analogicznym okresie rok wcześniej), natomiast koszty operacyjne (56,9 mln zł) nadal powodują generowanie straty netto ${ }^{37}$.

Kosztem olbrzymiego wysiłku finansowego Agora pozostaje wierna swojej agresywnej strategii dywersyfikacji. Jeden z jej fundamentów tworzy budowa grupy radiowej - projekt coraz bardziej dyskusyjny tak z punktu widzenia wewnętrznego potencjału rozwojowego, jak zarazem narzędzia realizacji założonego celu nadrzędnego, jakim jest umocnienie pozycji i wzrost wartości całej Grupy.

Według stanu na 30 czerwca 2003 roku koncern posiada udziały (w różnym procencie) w 24 spółkach radiowych zarządzających 28 stacjami lokalnymi i ponadregionalnym radiem TOK FM ${ }^{38}$. Problem Agory polega na fakcie wejścia w posiadanie rozgłośni lokalnych, a nie - zamiast nich - choćby jednej silnej stacji ogólnopolskiej. Choć bowiem Grupa szczyci się trzecią pozycją na rynku reklamy radiowej w Polsce, niemniej jej dystans do prowadzących (RMF FM i ZET), i tak potężny, coraz bardziej się powiększa (mimo przyłączania nowych rozgłośni). Obaj wymienieni powyżej potentaci dysponują w sumie około $56 \%$ rynku reklamowego w swoim segmencie - posiadając przy tym udział w słuchalności

36 Dzięki spłacie w marcu 2003 roku 34,9 mln zł pożyczki stan zadłużenia AMS S.A. wobec Agory S.A. wyniósł na koniec wymienionego miesiąca 30,1 mln zł.

37 Choć bez porównania mniejszej niż rok wcześniej (35,6 mln zł), co należy przypisać programowi restrukturyzacyjnemu.

38 Z tej liczby 22 spółki zostały objęte konsolidacją i ich wyniki są uwzględnione w bilansie Grupy Agora. 
przekraczający 40\%. Tymczasem niezbyt efektywne grupy rozgłośni lokalnych (w tym Agory) nie są w stanie osiagnąć założonych przychodów, mimo ponoszonych nieproporcjonalnie wysokich nakładów. Co gorsze, wartościowo „tort” reklamowy będący do podziału w segmencie radiowym nie jest szczególnie imponujący (około 8-9\% całego rynku) i ustępuje w Polsce nie tylko telewizji, ale także magazynom i gazetom. Zarząd Agory w swoim komentarzu do Raportu za I półrocze 2003 roku zapowiada co prawda, że ,...kierownictwo pionu radiowego pracuje nad projektem restrukturyzacji grupy radiowej, której celem jest odwrócenie niekorzystnych tendencji w udziale w rynku reklamy radiowej i udziale w rynku słuchalności stacji radiowych oraz optymalizacja kosztów operacyjnych [...]", niemniej - skoro skonsolidowane przychody ze sprzedaży uzyskane za ten okres przez intensywnie rozbudowywaną grupę radiostacji wynoszą 20,2 mln zł (wzrost zaledwie o 1,5\%), generując stratę $8,1 \mathrm{mln}$ zł (rok wcześniej 4,8 mln) - rodzi się pytanie o przyszłość tego przedsięwzięcia. Jeżeli nie uda się doprowadzić go do wewnętrznej konsolidacji i pełnego aliansu sprzedażowego, być może pewnego dnia Agora stanie przed koniecznością podjęcia decyzji o jego sprzedaży.

W 2003 roku Agora kontynuuje program oszczędnościowy. Stopniowo cięte jest zatrudnienie (za okres styczeń-czerwiec 2003 roku średnio o 2,8\% w stosunku do analogicznego okresu rok wcześniej), również choć wolniej - spada koszt wynagrodzeń $(-1,2 \%)$. Obniżeniu ulegają wydatki na materiały i energię.

Kierownictwo Agory zdaje sobie sprawę z konieczności dalszego „zaciskania pasa" w nadchodzącym okresie. Potwierdzi to m.in. ogłoszony kilka miesięcy później (29.01.2004 r.) komunikat informujący, że „,..Zarząd Agory S.A. podjął decyzję o rozpoczęciu procesu restrukturyzacji Spółki [...]. Chodzi o zwiększenie efektywności działania. Elementem realizacji tej strategii jest redukcja kosztów operacyjnych. Wynika ona m.in. ze zmiany sposobu funkcjonowania i przemodelowania procesów: centralizacji pewnych funkcji, jak np. finanse czy zarządzanie kadrami, optymalizacja kosztów materiałowych, renegocjowanie umów z partnerami [... $]^{339}$. Zgodnie z szacunkami zarządu wdrożenie pierwszego etapu planowanych działań restrukturyzacyjnych ma zapewnić co najmniej $25 \mathrm{mln}$ zł oszczędności rocznie, począwszy od 2005 roku. To dość dużo,

39 Stanowisko Spółki w sprawie zawiadomienia Urzędu Pracy o zwolnieniach grupowych (29 stycznia 2004 r.). 
choć zarazem zbyt mało - jeżeli w międzyczasie nie zapadną decyzje modyfikujące dotychczasową strategię inwestycyjną ${ }^{40}$. Balastem finansowym Agory są „młode” projekty, same w sobie wymagające restrukturyzacji, po czym pełnej (nie tylko finansowej) konsolidacji z resztą koncernu. Część z nich nieprędko jeszcze „odpowie” na pytanie co do możliwego do zrealizowania potencjału rozwojowego i przyszłej opłacalności. Niektóre zapewne trzeba będzie z czasem odrzucić, godząc się ze stratami (naiwnością byłoby liczenie na 100\% „trafień).

W przeciwieństwie do Agory, która musi walczyć o byt na własnym, dopiero dojrzewającym (a przez to niestabilnym) rynku, Springer posiada w swoim kraju od dawna ugruntowaną pozycję zarówno w segmencie dzienników, jak i czasopism. Sygnalizowane przez niego inwestycje zagraniczne mają podnieść wartość ASV - ale ewentualne niepowodzenie którejkolwiek z nich nie niesie praktycznie żadnego zagrożenia dla jego sytuacji finansowej. Pakiet działań restrukturyzacyjnych o kluczowym znaczeniu, które dopiero czekają Agorę, koncern Springera ma już praktycznie za sobą. Jego bieżącą strategię najlepiej podsumowuje wypowiedź prezesa Döpfnera z 14 sierpnia 2003 roku: ,...nieustannie pracujemy nad optymalizacją struktury kosztowej Grupy i w pierwszej połowie roku osiągnęliśmy dalszy znaczący postęp na tym froncie [...]. Ale sytuacja rynkowa pozostaje ekstremalnie trudna. W związku z tym będziemy kontynuować program restrukturyzacyjny w drugiej połowie roku. Jednocześnie planujemy inwestycje w nowe gazety i magazyny [...]”. I taką właśnie inwestycją Springera jest polski „Fakt”.

Z punktu widzenia Agory trudno chyba o gorszy moment na wejście na rynek tego tytułu. Konieczność przegrupowania środków w celu obrony pozycji grozi zburzeniem strategii stopniowego budowania silnej i zarazem kompletnej grupy medialnej. Strategii znajdującej się w punkcie, w którym skala środków zaangażowanych w nowe projekty nie pozwala na wycofanie się z nich bez poważnych strat. Tymczasem pojawia się konkurent, dla którego rynek polski - o dużej liczbie ludności, relatywnie otwarty i nie do końca zagospodarowany - stanowi teren naturalnej ekspansji. Jest bardzo cenny z prostego powodu: spóźnienia Springera z in-

40 Jej przegląd oraz przeformułowanie i tak wydaje się nieuchronne choćby ze względu na wpływ skutków tzw. afery Rywina (nie omawiamy jej przebiegu i konsekwencji dla Agory ze względu na liczne analizy i artykuły prasowe, jakie się już ukazały w minionym okresie). 
westycjami w Europie Zachodniej (przez co rynki medialne tych krajów są już dla niego niemal zamknięte).

Agora ma prawo obawiać się narzucenia jej przez ASV jego reguł gry. Springer hołduje zasadzie tworzenia kompletnej grupy prasowej. Buduje jąjak klocki Lego, stopniowo wypełniając luki. W Niemczech następnym tytułem po bulwarówce „Bild” był dziennik opinii „Die Welt”. Watpliwe, aby w Polsce ambicje Springera w segmencie prasy opiniotwórczej mógł zaspokoić licencyjny „Newsweek Polska”. Agora, zamiast kontynuować swoją suwerenną strategię, będzie musiała odpowiedzieć na taki krok. Tak samo, jak na więcej niż prawdopodobne wejście Springera na rynek prasy niedzielnej. Nie wystarczy wówczas bariera tworzona przez weekendowe wydanie „Gazety Wyborczej”,

W Grupie ASV Agora trafia na trudnego przeciwnika, zdecydowanego poszerzyć portfel przedsięwzięć na rynku polskich mediów. Interesuje go wyłącznie wiodąca pozycja na rynku i posiada środki do jej osiągnięcia. Springer poszukuje przy tym efektu synergii w skonsolidowanych, ściśle uzupełniających się przedsięwzięciach prasowych. Odmiennie niż Agora, starająca się wyzyskać synergię z wzajemnego wspierania się przez zdywersyfikowane projekty.

Jakich dalszych posunięć strategicznych na rynku polskim możemy oczekiwać ze strony Agory i Springera, głównych graczy w tej rozgrywce? Na pomyłki nie stać przede wszystkim wydawcy „Gazety Wyborczej”, który 2003 rok zamyka zyskiem netto na poziomie zaledwie $2,1 \mathrm{mln}$ zł i wzrostem kosztów operacyjnych o ponad $18 \%$ - w czym zasługa m.in. $36 \mathrm{mln}$ zł przeznaczonych na obronę pozycji „Gazety” w samym tylko ostatnim kwartale roku. Obronę dość skuteczną, ale dzięki nakładom, których skala wydaje się nie do udźwignięcia w dłuższym okresie czasu ${ }^{42}$.

Czy oznacza to, że strategia Agory, tak agresywna i uparcie forsowana przez lata, może ponieść porażkę? Pytanie pozostaje otwarte.

41 Równie duże zagrożenie istnieje dla Orkli i Passau - trudno przypuszczać, aby Springer z jego doświadczeniem w wydawaniu gazet regionalnych i lokalnych (także za granica, np. na Węgrzech) całkowicie ominął ten segment.

Ostatnie dwa kwartały 2003 roku Agora zamknęła stratą netto (odpowiednio $5,9 \mathrm{mln}$ i 0,2 mln zł), mimo wcześniejszych prognoz przewidujących niewielki zysk. 


\section{Summary}

The transformation of Polish society and economy over the last two decades is also reflected in the process of the press market becoming mature. The segments of this market transform assuming a strong market economy character. New dominating players emerge representing both domestic and - increasingly often - foreign capital.

The foundation and expansion of the Agora Group, the publisher of „Gazeta Wyborcza" inspires peculiar common interest (or even fascination). It is usually presented rather one-sidedly as a Polish version of an American ,rags-to-riches” story. The organizational and financial aspect of the Group operations is usually neglected or oversimplified.

This paper was written in the first quarter of 2004. It tries to show the publisher of „Gazeta Wyborcza" not with respect to its media mission but to its economic aspect. The management board of this business outlines and tries to implement a certain strategy. However, in doing so they apparently fail to avoid considerable errors and threats. 